\title{
Extraction of Oil, Biogas and Biodiesel from Moringa oleifera Seeds.
}

Emmanuel O. Ahaotu, Reginald E. Uwalaka, Maxwell C. Edih and Pius O. Ihiaha

Department of Animal Production and Health Technology, Imo State Polytechnic Umuagwo, Nigeria.

Corresponding author: emmaocy@yahoo.com

\begin{abstract}
The present work was on the extraction of the oil from the Moringa (Moringa oleifera) kernel as a source for biodiesel and biogas production. Moringa is an indigenous tree in India. Several extraction methods are used to determine the extraction yields, solvent extraction ( $n$-hexane and ethanol), and supercritical extraction $\left(\mathrm{Sc}-\mathrm{CO}_{2}\right)$ respectively. Supercritical extraction pressures of 200 to $400 \mathrm{bar}$ and temperatures of $40^{\circ} \mathrm{C}$ and $60^{\circ} \mathrm{C}$ were tested. Gas Chromatography analysis revealed that the main fatty acids in Moringa oil are oleic acid (69\%), palmitic acid $(10 \%)$ and stearic acid $(8 \%)$.
\end{abstract}

Keywords: (Moringa oleifera, $\mathrm{CO}_{2}$ Supercritical Extraction, Solvent Extraction, Ben Oil)

\section{Introduction}

Moringa oleifera Lam belonging to the family Moringaceae is a handsome softwood tree, native of India and now grown world-wide in the tropics and sub-tropics. In India, it is grown all over the subcontinent for its tender pods and also for its leaves and flowers. The pods of moringa are very popular vegetables and valued for its distinctly inviting flavour.

Moringa oleifera is considered as "miracle tree" because all its parts are used, especially for their pharmacological, nutritional and purifying water properties. Leaves are eaten as vegetables and pressed; they are used in traditional pharmacology to treat many aliments. The fruits are mainly used in condiments or cooked as vegetables. Flowers produce nectar and have anti-inflammation properties. Moringa seeds are rich in proteins and oil, traditionally are used for beauty care. Seeds are also used for water purification. The wood provides a blue dye and it is used for live fences. Medicinal qualities offer to treat diabetes, to enrich anaemic blood, to staunch a skin infection, to be an antibiotic, to heal gastric ulcers and to care eyes. Thus, this tree offers very interesting opportunities as food supplement, nutrition, vegetable, oil, water treatment, green manure, foliar spray, natural fertilizer, livestock feed, fodder, medicine, cosmetic and care products.

The oil extracted from Moringa is known as ben oil and reportedly contains $70 \%$ of oleic acid, an 18carbon long monounsaturated fatty acid (MUFA). Since the oleic acid has good oxidative stability when compared with polyunsaturated fatty acids (PUFAs), it is useful in the food industry, as it encourages longer storage and high-temperature frying processing. The oil content of de-hulled seed (kernel) is approximately $42 \%$. The oil is yellowish in colour. It is also used as a lubricant for fine machinery because of its little tendency to deteriorate, become rancid and sticky (Ahaotu, 1997). In some areas, it serves as vegetable cooking oil. The oil is known for its capacity to absorb and retain volatile substances and is therefore valuable in the perfume industry for stabilizing scents. The free fatty acid content varies from 0.5 to $3 \%$. The seed oil of Moringa contains approximately $13 \%$ saturated fatty acids and $82 \%$ unsaturated fatty acids. It has a particularly high level of oleic acid (70 \%) (Abdulkarim et al., 2007).

Ben oil is more stable than canola oil, soybean oil and palm oil when used in frying. Blending ben oil with sunflower oil and soybean oil enhances the oxidative stability of the mixture. Mani et al. (2007) and Ahaotu et al., (2013b) stated that comparing its chemical properties, Moringa seed oil is considered equivalent to olive oil and may be used for human consumption. Also, the oil from Moringa seeds has shown the strongest anti- fungal activity against a zoophilic dematophyte caused marked inflammatory reactions in humans (Chuang et al., 2007; Ahaotu et al., 2013a).

Solvent extraction has been reported by Mani et al. (2007) using $n$-hexane, petroleum ether and acetone. Experimental Soxhlet extraction using $n$-hexane and ethanol, and also supercritical extraction with $\mathrm{CO}_{2}$ on Moringa seeds have been reported by Nguyen et al. (2011). Sovova and Stateva (2011) recently review the field of supercritical extraction of vegetable materials and reported appreciations in industrial applications.

Moringa seeds as biosorbent could be used as a less expensive biosorbent for the removal of cadmium (Cd) from aqueous media (Sharma et al., 2006). The amino acids found in moringa seeds constitute a physiologically active group of binding agents, which has the ability to interact with metal ions to increase the sorption of metal ions (Sharma et al., 2006; Brostlap and Schuurmans, 1988).

Moringa plants (approximately 30 days old) were milled together with water. The fibre was separated by filtration through a mesh with $5 \mathrm{~mm}$ pores and the liquid fraction produced was then added. With an average feed of $5.7 \mathrm{~g}$ of volatile solids the gas production was 580 liters of gas per $1 \mathrm{~kg}$ of volatile solids. The average methane content of the gas was 81 $\%$ (Broin et al., 2002). 


\section{Materials and method}

\section{Collection of Moringa seeds}

The Moringa oleifera seeds used for this work were obtained from a Moringa plantation at the Forestry unit, Imo State Polytechnic Umuagwo, Nigeria.

\section{Processing of Moringa seeds}

Moringa oleifera kernels were cleaned to remove stones, dirt, sand and other extraneous materials. The cleaned kernels were cracked by hand to remove the shell from the nuts. The seeds were divided into three equal parts; a part of the seeds were dried in the cabinet oven at $60^{\circ} \mathrm{C}$ for 2 hours; after which it was milled to flour in an attrition mill to obtain a smooth Moringa oleifera seeds flour. Another portion was sundried at the normal atmospheric temperature for 4 days and milled to obtain the flour while the last part was not subjected to any drying method (serves as control sample).

\section{Extraction of Moringa seed oil}

The smooth flours (500g each) were transferred inside a jar bottle and $400 \mathrm{ml}$ of hexane was poured inside the jar for 24hours. The samples were mixed together by shaking and was turned into a round bottom flask of the Soxhlet extractor and covered with the reflux condenser subjecting the bottom of the flask to heat. The solvent was allowed to boil gently and left to siphon over a period of 2 hours. The boiling point of hexane is lower than that of the oil, hence hexane was evaporated leaving the oil; and hexane was collected. The oil obtained from the extract was allowed to dry in an oven at $105^{\circ} \mathrm{C}$ for 2 hours and cooled in a desiccator before using for experimental work. The oil obtained is called crude oil because it has not been refined. Oil sample was also extracted from freshly harvested Moringa oleifera seeds without subjecting it to any processing as the control sample.
Table 1. Proximate Analysis of Moringa oleifera

\begin{tabular}{ll}
\hline Characteristics & Obtained Values \\
\hline Moisture & $10.50 \pm 0.71$ \\
Ash & $5.00 \pm 0.00$ \\
Crude fiber & $5.00 \pm 0.00$ \\
Crude protein & $39.57 \pm 3.23$ \\
Fat & $32.50 \pm 7.78$ \\
Carbohydrate & $7.44 \pm 10.30$ \\
\hline
\end{tabular}

The GC and GC-MS analysis of the seed oil of $M$. oleifera was performed using a multi-dimensional gas chromatography coupled with gas chromatographymass spectrophotometer. (Shimadzu Japan) equipped with non-polar and polar double capillary columns $(25.0 \mathrm{~m} \times 0.25 \mu \mathrm{m}$ i.d., $0.25 \mu \mathrm{m})$. High purity helium was used as the carrier gas at a constant flow rate of $0.99 \mathrm{ml} / \mathrm{min}$. $1 \mu \mathrm{l}$ sample was injected (split ratio
100:1) into GC and GCMS using AOC-2Oi; auto injector for analysis. The initial temperature was set at $60^{\circ} \mathrm{C}$, heated at a rate of $3^{\circ} \mathrm{C} / \mathrm{min}$ to $280^{\circ} \mathrm{C}$ and held isothermally for 6 minutes. Ion source temperature was set to $200^{\circ} \mathrm{C}$ while the interface was set at $250^{\circ} \mathrm{C}$; solvent cut time was 3 minutes. Electron impact (EI) ionization mode was $70 \mathrm{ev}$ and the linear velocity of the column was $36.8 \mathrm{~cm} / \mathrm{sec}$.

Plate 1. Seeds of Moringa oleifera

Plate 2. Moringa oleifera Seed and Powder

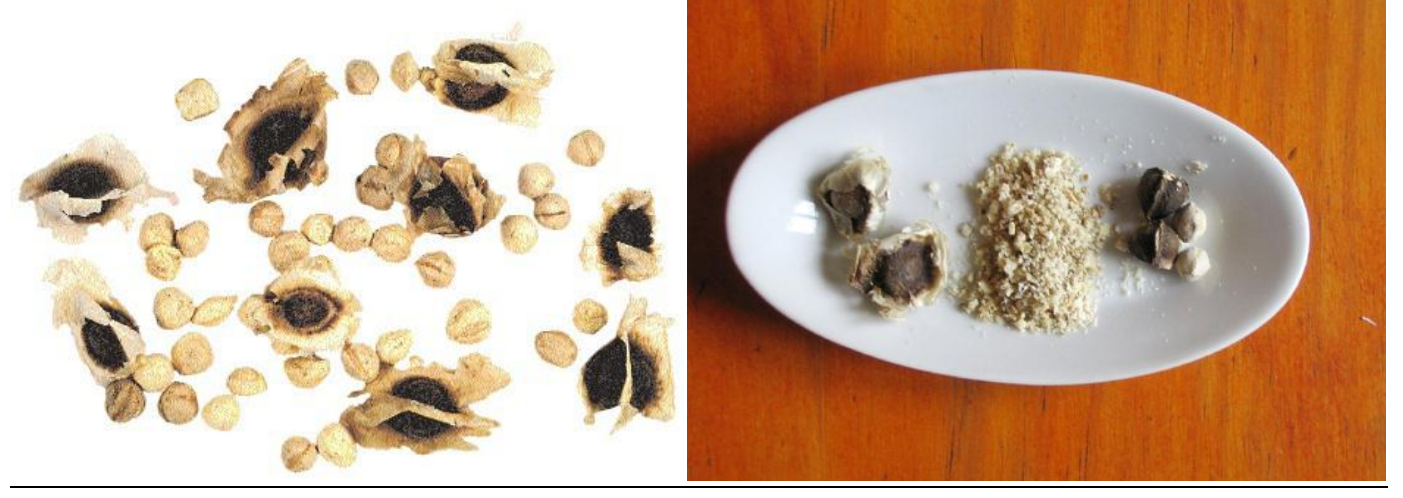

Plate 3. Ben oil extracted from Moringa oleifera seeds. 


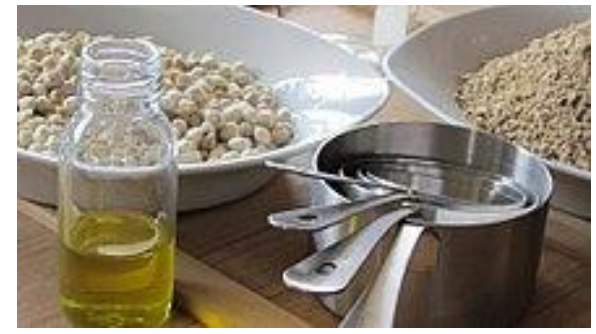

Table 2. Proximate Composition of Ben Oil

\begin{tabular}{ll}
\hline Components & Percentages (\%) \\
\hline Myristic acid & 0.1 \\
Palmitic acid & 9.3 \\
Stearic acid & 7.4 \\
Behenic acid & 8.6 \\
Oleic acid & 65.5 \\
Palmitoleic acid & 1.4 \\
Linoleic acid & 1.5 \\
Arachidic acid & 3.7 \\
Eicosenoic acid & 2.3 \\
Cerotic acid & 1.3 \\
Phytosterols & 9.0 \\
\hline
\end{tabular}

\section{Results and discussions}

The oil extracted from M. oleifera seed has an agreeable odour and the colour is cream-yellow, the percentage oil yield is $38 \%$. This percentage yield was higher' than that reported by (AOAS, 2001), where the seed oil yield of M. oleifera was 34.50. The 38\% yield of $M$. oleifera was consistent with that of Literature (Lalas and Tsaksins, 2002). The specific gravity of M. oleifera seed oil was 0.9050 and this value is in agreement with the FAO/WHO (2009) international standard for edible oil. The refractive index 1.4559 was in agreement with the FAO/WHO (2009) international standard for edible oil. The physical properties of the oil extracted from $M$. oleifera seed were in conformity with the FAO/WHO (2009) standard. On the other hand, the chemical properties of the oil are shown also in table 1. An acid value of $6.73 \mathrm{mg} / \mathrm{KOHg}-1$, this value is higher than the acid value specified for edible oil by FAO/WHO (2009) but this value was almost in agreement with Literature $(5.0386 \mathrm{mg} \mathrm{KOH} / \mathrm{g}$ ) reported by (AOAC, 2006)

Result of the proximate composition of M. oleifera seed oil is shown in table 1 . The moisture content is $10.50 \%$, ash content, $5.00 \%$, crude fiber $5.00 \%$, crude protein $39.57 \%$, fat content $32.50 \%$ and carbohydrate (by difference) $7.44 \%$. The observed low moisture content in M. oleifera seed in this study serve as an indication that the activities of the micro-organisms would be reduced and thereby increases the life of $M$. oleifera sample. The observed moisture content value of $10.50 \%$ is higher than the value $(9.40 \%)$ reported by (Aja et al., 2013). The ash content is $5.00 \%$ which is higher than the value (3.87\%) reported by (Aja $e t$ al., 2013) but in agreement with the value (5.00\%) reported by (Peter and Philip, 2014). Ash is an incombustible residue left after complete combustion of any substance. The crude fiber content of $5.00 \%$ obtained in our sample was higher than $2.87 \%$ reported by (Aja et al., 2013) but lower than $20.00 \%$ reported by (Peter and Philip, 2014) from Ebonyi State, Nigeria, crude fiber content has been established to help in bowel movement. Adequate intake of dietary fiber can lower cholesterol level, risk of coronary heart diseases, constipation, hypertension, diabetes, colon and breast cancer (Adegbe et al., 2016). Crude protein and fat content are $39.57 \%$ and $32.50 \%$ respectively. The crude protein content is higher than $35.97 \%$ and $9.98 \%$ reported by (Masurekar et al., 2015) while the observed fat content in this study is lower than $38.62 \%$ and $40.00 \%$ reported by (Aja et al., 2013). Adegbe et al., (2016) stated that plant food provide more than $12 \%$ of its calorific value from protein, is considered good source of protein. Therefore, M. oleifera is a good source of protein. Carbohydrate content is $7.44 \%$ which is lower compared to the value 18.00 reported by (Peter and Philip, 2014).

The chemical components of the fixed oil $M$. oleifera seed oil was analyzed using multidimensional gas chromatography coupled with gaschromatography-mass spectrophotometer (GC-MS). Twenty four (24) components amounting to $96.81 \%$ were identified in the seed oil. The identified components, their retention indexes and percentage composition of each component are shown in the table 2 above. The major constituents found in the fixed oil of $M$. oleifera seed oil are: Oleic acid (22.51\%), Palmitic acid (10.64\%), Stearic acid (6.07\%), 9octadecenal (12.76\%) and Phenyl but-3-1-yne $(5.79 \%)$. Other noticeable constituents found in the oil were o-Ethyltoulene (4.64\%), m-Propyltoulene (3.56\%), 4-methylindin (2.35\%), 2-phenyl-2-pentane 
(2.47\%), p-mentha -1, 3, 8-triene $(2.36 \%)$ and Arachidic acid $(2.21 \%)$. It is worth mentioning that the main compounds characterizing the fixed oil of $M$. oleifera are qualitatively and quantitatively different. The fixed oil of $M$. oleifera is rich in fatty acid $(44.93 \%)$ followed by hydrocarbons $(32.95 \%)$, others are aldehyde (12.76\%), esters (3.55\%) and Oxygenated hydrocarbons $(2.62 \%)$. The following fatty acids were identified from the GC-MS analysis: Oleic acid (22.51\%) was the major component of the fixed oil. Oleic acid is a mono-saturated omega-9fatty acid with many health benefits and is safe in present practices for use and concentrations in cosmetics (Liebert 1987). Oleic acid prevents ulcerative colitis (De Silver et al., 2014), protects cell from free radical damage (Haug et al., 2007), reduces blood pressure (Ruiz-Gutirrez et al., 1996) and increases fat burning (Lim et al., 2013). Palmitic acid is a saturated long chain fatty acid with sixteen carbon backbone. It is one of the most abundant and wide spread natural saturated acids present in plants like palm oil, palm kernel oil, M. oleifera seed oil, in animals and animal-derived foodstuffs like cheese, milk, meat and microorganisms (Lim et al., 2013). It is among the fatty acid that is used as concentration in cosmetics (Adegbe et al., 2016).

Arachidic acid (icosanoic acid $\mathrm{C}_{2} \mathrm{OH} 40 \mathrm{O}_{2}$ ) is a saturated long-chain fatty acid with 20-carbon backbone found naturally as a minor component of peanut oil, also found in M. oleifera seed oil. It is used in the industry as component of adhesive, sealant and lubricants, as lubricant additive or in agricultural products. Stearic acid (octadecanoic acid), a saturated fatty acid having 18-carbon chain was formed in $M$. oleifera seed oil. Stearic acid is mainly used in the production of detergent, soaps and cosmetics such as shampoos and sharing cream products. Soap is made saponification of triglycerides consisting of stearic acid esters. Surfactants, cosmetics and personal hygiene products are in fact prospects of stearic acid (Gunstone, 2014).

Myristic acid was also found as one of the constituents of $M$. oleifera seed oil. It is a saturated fourteen (14) carbon fatty acid found naturally in palm oil, coconut oil and butter fat. Myristic acid is used as a flavoring agent in food (Morton, 1991 and Adegbe et al., 2016) and also used as emulsifiers, emollient and lubricants in variety of cosmetics, creams, cake, soaps and pastes (Farooq and Umar, 2007). It is an important fatty acid which the body uses to stabilize many different proteins, including protein in the immune system. Erucic acid also known as (Z)docos-13-enoic acid was also present in $M$. oleifera seed oil. It is a monounsaturated omega-9-fatty acid with twenty-two carbon atoms.

Docosanoic acid (Behenic acid) is a major component of Ben oil which is extracted from the seed of M. oleifera (Quattrocchi and Umberto, 2000) and found in the seeds of $M$. oleifera sample of this present study. It is used to give hair conditioners and moisturizers their smoothing properties (Bulus, 2000).

\section{Conclusion}

Moringa seed oil could be utilized successfully as a source of edible oil for human consumption. The physio-chemical parameters of the oil are comparable to those of other edible oil, therefore flour from $M$. oleifera seeds could be employed in the fortification of other food materials. The results from the study also showed that the properties of M. oleifera oil in Nigeria could be employed for edible and cosmetics application. The seed oil exhibited good physiochemical properties and could be useful for industrial applications.

\section{Acknowledgement}

The authors wish to thank the Executive Director, TETFUND for providing necessary facilities to conduct present study.

\section{References}

Abdulkarim, S.M, Long, M, Lai, O.M, Muhammad, S. K. S and Ghazali, H. M. (2007): "Frying Quality and Stability of High-Oleic Moringa oleifera Seed Oil in Comparison with Other Vegetable Oils," Food Chemistry, Vol. 105, No. 4: 1382-1389.

Adegbe A. A., Larayetan R. A. Omojuwa T. J. (2016): Proximate Analysis, Physicochemical Properties and Chemical Constituents Characterization of Moringa oleifera (Moringaceae) Seed Oil Using GC-MS Analysis American Journal of Chemistry . 6 (2): $23-28$

Ahaotu, E.O, Osuji, C.N. Nwabueze. E.U Ibeh, C.C (2013a): Benefits of Jathropha gossipifolia in Nigeria. Inter J Agri Biosci, 2(6): 349 - 355.

Ahaotu, E.O, Uwalaka, R.E Ayo - Enwerem, C.M (2013b): Enhancing Maize Stover utilization by West African Dwarf Sheep using Moringa oleifera. Inter J Agri Biosci, 2(4): 153-155.

Ahaotu, E.O. (1997): Indigenous Agroforestry: Moringa oleifera in Nigeria. Acacia, 14: 14-17.

Aja, P.M, Ibiam, U.A, Uraku, A.J, Orji, O.U, Offor, C.E Nwali, B.U (2013): Comparative, Proximate and Mineral Composition of Moringa oleifera Leaf and Seed. Global Advanced Research Journal of Agricultural Science. Vol 2 (5). Pp137141.

AOAC (2006): Official Method of Analysis of AOAC International. 18 th Edn., Gaithersburg, USA. Pp $78-83$

AOAS (2001): Official methods and recommended practices of the American Oil Chemists Society. 6 th Edn., 2001, AOCS Press, Champaign. Pp43-46

Broin M, Santaella C, Cuine S, Kokou K, Peltier G, and Joet T. (2002): Flocculent activity of a recombinant protein from Moringa oleifera Lam. seeds. Appl Microbiol Biotechnol 60: 114- 119. 
Brostlap AC and Schuurmans J. (1988): Kinetics of valine uptake in tobacco leaf disc. Comparison of wild types the digenic mutant and its monogenic derivatives. Planta 176: 42-50.

Bulus A. (2001): Behenic Acid Notification. Flamm Associates. Vero Beach. Pp:3-4.

Chuang, P.H, Lee, C.W, Chou, J.Y, Murugan, M, Shieh, B.J and Chen, H.M (2007): "Antifungal Activity of Crude Extracts and Essential Oil of Moringa oleifera Lam.," Bio- resource Technology, Vol. 98, No. 1: pp. 232-236.

De Silver PS, Luben R, Shrestha SS, Khaw KT and Hart AR. (2014): Dietary arachidonic and oleic acid intake in ulcerative colitis etiology: A prospective cohort study using 7-days food diaries. Eur. J. Gastroenterol Hepatol. 26 (1): 11-8 [PubMed]

Farooq A and Umar R (2007): Physicochemical characteristics of $M$. oleifera seed and seed oil from a wild province of Pakistan. J. Bot. 39(5):1443-1453.

FAO/WHO (2009): Report on the 21st session of the Codex Alimentarius Committee on fats and oils. Kola Kinabalu, Malaysia.

Gunstone, F.D (2014): The Chemistry of Oils and Fats, sources, composition, properties and uses. Blackwell Publishing Ltd, UK.

Haug A, Hestmark AT and Harstad OM. (2007): Bovine milk in human nutrition-a review. Lipid Health and Disease. 6:25. [PubMed].

Lalas S and Tsaksins J. (2002): Characterization of Moringa oleifera seed oil variety. "Periyakulam 1'. J. Food Comp. and Anal. 15: 65-77.

Liebert, M.A. (1987): Final Report on the Safety Assessment of Oleic acid, Laurie acid, Palmitic acid, Myristic acid and Stearic acid. Journal of American College of Toxicology. 6(3): 321-402.

Lim JH, Gerhart-Hines Z, Doming JE, Lee Y, Kim S, Tabata M, Xiang YK and Puigserver P. (2013): Oleic acid stimulates complete oxidation of fatty acids through protein kinase A-dependent activation of SIRT1-PGC1 $\alpha$-complex- J. Biol Chem. 288:7117-26. [PubMed].

Mani, S, Jaya, S and Vadivambal, R (2007): "Optimization of Solvent Extraction of Moringa (Moringa oleifera) Seed Kernel Oil Using
Response Surface Methodology," Food and Bioproducts Processing: Transactions of the Institution of Chemical Engineers Part C, Vol. 85, No. 4: 328-335.

Masurekar .S, Kadam.V and Jadhav.V (2015): Roles of Moringa oleifera in medicine-A Review. World Journal of Pharmacy and Pharmaceutical Sciences 4: 375-385.

Morton, J.F (1991): The Horse radish tree, Moringa pterygospermin. A boom to arid lands. Economic Botany, 45:318-333.

Nguyen, H.N, Gaspillo, P.D, Maridable, J. B, Malaluan, R. M, Hinode, H, Salim, C and Huynh, H. K (2011): "Extraction of Oil from Moringa oleifera Kernels Using Supercritical Carbon Dioxide with Ethanol for Pretreatment: Optimization of the Extraction Process," Chemical Engineering and Processing: Process Intensification, Vol. 50, No. 11-12 pp. 1207-1213.

Peter, T.O and Philip, C.A.N (2014): Proximate Analysis and Chemical Composition of Raw and Defatted Moringa oleifera Kennel. Advances in Life and Tech. J. Vol 24.

Quattrocchi, G and Umberto, N (2000): CRC World Dictionary of Plants Names: Common Names, Scientific Names, Eponyms, Synonyms and Etymology. 3. CRC Press. P. 1731.

Ruiz-Gutirrez V, Munana FJ, Guerrero A and Cert AM, Villar J. (1996): Plasma Lipids erythrocytes membrane lipids and blood pressure of hypertensive women after ingestion of dietary oleic from two different sources. J. Hypertens. 14: 1483-1490. [PubMed].

Sharma, P, Kumari, P, Srivastava, M.M and Srivastava, S. (2006): Removal of cadmium from aqueous system by shelled Moringa oleifera Lam. seed powder. Bioresour Technol 97: 299-305.

Sovová, H and Stateva, R. P (2011): "Supercritical Fluid Extraction from Vegetable Materials," Reviews in Chemical Engineering, Vol. 27, No.34, pp. 79-156. 